\title{
PCR negative cerebral malaria in a traveller returning from Mumbai
}

\author{
Rohan Bhome, ${ }^{1}$ Rahul Bhome ${ }^{2}$ \\ ${ }^{1}$ UCL Medical School, University College London, London, UK; \\ 2Department of Acute Medicine, Northwick Park Hospital, Harrow, Middlesex, UK
}

Correspondence to Mr Rohan Bhome, rohan.bhome@ucl.ac.uk

\begin{abstract}
Summary
The incidence of imported malaria to the UK is significant. The authors report a case of a healthy young man diagnosed with PCR negative cerebral malaria, a week after returning from Mumbai. The patient presented with acute confusion and vomiting. His condition deteriorated quickly warranting intubation, ventilation and transfer to intensive therapy unit. Extensive investigation did not find an underlying cause. Antimalarial treatment was initiated based on clinical suspicion despite a negative malarial screen. A rapid response to treatment followed such that the patient was extubated within $24 \mathrm{~h}$. This case highlights the need for the UK Health Protection Agency to review its risk classification of malaria for travellers to Mumbai. Additionally, clinicians should promptly initiate antimalarial treatment in an unwell traveller returning from an endemic area when there is a high clinical suspicion even in the absence of a positive initial malaria screen.
\end{abstract}

\section{BACKGROUND}

Increasing travel to endemic areas by returning migrants and holidaymakers means that the incidence of imported malaria to the UK remains high. The Health Protection Agency (HPA) reports that over the past 20 years there have been between 1370 and 2500 reported cases of imported malaria in the UK each year. ${ }^{1}$ Indeed, a recent capture- recapture study by Cathcart and coworkers ${ }^{2}$ shows that these figures are likely to be an under-representation. Worryingly, the proportion of cases attributed to the most fatal falciparum species is increasing and has accounted for over $75 \%$ of imported malaria in the last 5 years. The relative lack of experience in dealing with malaria and its sequalae in the UK can make treatment difficult. Consequently, prevention in the form of chemoprophylaxis is better than cure.

This case is important for a number of reasons. First, it emphasises the rapidly progressive nature of cerebral malaria, the presentation of which can be vague. Second, it demonstrates that Mumbai is a city in which travellers are at significant risk of malaria, despite the UK HPA describing the risk as extremely low. ${ }^{3}$ Lastly, it sets a precedent for the management of this disease, in the context of a negative malarial screen.

\section{CASE PRESENTATION}

We report a case of a previously well 21-year-old man who presented to the emergency department with acute confusion and vomiting, 1 week after returning from Mumbai, India, where he had been partially compliant with an antimalarial regimen of chloroquine and proguanil. A collateral history taken from the patient's next of kin did not reveal any previous medical, family or social history of note. On examination, the patient was apyrexial and haemodynamically stable, with marked agitation and glasgow coma scale $9 / 15$. There were no focal neurological signs. Multiple bite marks were noted on the lower limbs, consistent with mosquito bites.

\section{INVESTIGATIONS}

CT of the head was unremarkable and lumbar puncture demonstrated a normal opening cerebrospinal fluid pressure, normal biochemistry and negative bacterial culture. Initial blood tests showed leucocytosis $\left(18.4 \times 10^{9} / 1\right)$, hyponatraemia $(126 \mathrm{mmol} / \mathrm{l})$ and mild hyperbilirubinaemia $(20 \mu \mathrm{mol} / \mathrm{l})$. Initial malarial antigen and blood films were negative. Blood cultures were negative. Malarial PCR was later reported as negative.

\section{DIFFERENTIAL DIAGNOSIS}

After initial assessment, the differential diagnoses included meningitis, encephalitis and cerebral malaria.

\section{TREATMENT}

The patient was treated empirically for bacterial meningitis and viral encephalitis with ceftriaxone and acyclovir. Urgent elective intubation and ventilation were conducted and the patient was nursed in an intensive therapy unit setting. On day 3, without showing any signs of recovery, intravenous quinine was commenced to cover for cerebral malaria even though three consecutive thick and thin blood films and malarial antigen had been negative. There was a prompt response such that the patient was extubated on day 4 and stepped down to the general ward on day 5. An oral antimalarial regimen of quinine and doxycycline was then continued for 7 days.

\section{OUTCOME AND FOLLOW-UP}

Having completed his course of antimalarial medication, the patient was discharged from hospital on day 12 and resumed all of his premorbid activities within 2 weeks. 
Eighteen months on, the patient remains fit and well, with no physical or psychological complications of his illness.

\section{DISCUSSION}

There are no cases in the literature describing cerebral malaria as the most likely diagnosis in an unwell returning traveller with negative blood films, serology and PCR.

Did the patient actually have cerebral malaria? There are a number of arguments which would support this diagnosis despite negative blood films, serology and PCR. False negative malarial tests can occur if the patient has taken partially effective prophylaxis. ${ }^{4}$ Clinical features including rigors and unexplained hyponatraemia ${ }^{5}$ are consistent with falciparum malaria. Significantly, the patient made a rapid recovery following intravenous quinine treatment. Finally, the consultant microbiologist, based on many years of experience working in endemic malarial areas, felt that the presentation was in keeping with that of cerebral malaria.

Mumbai, in the state of Maharashtra, is an increasingly popular holiday destination among British travellers. The National Travel Health Network and Centre describes the risk of malaria in Mumbai as being 'very low' and suggests that chemoprophylaxis is not required. ${ }^{3}$ This advice is supported by the HPA Advisory Committee on Malaria Prevention (ACMP) and is given to travellers. However, there is a growing incidence of malaria in Maharashtra with 200000 positive cases between 2009 and 2010, resulting in over 320 deaths. ${ }^{6}$ Media reports suggest that the majority of these cases are occurring in Mumbai. ${ }^{7}$ Limited figures from the Municipal Cooperation for Greater Mumbai showed that there were 20000 confirmed malaria cases and 40 deaths in Mumbai between January and August 2010 alone, ${ }^{8}$ confirming its endemic nature. Given that local incidence correlates with the risk for travellers, ${ }^{9}$ these figures clearly suggest increased risk for those returning from this city.

Cerebral malaria is potentially fatal and is rapidly progressive. Current malaria guidelines ${ }^{10}$ advise that in the absence of a positive diagnosis, malarial treatment should not be initiated unless expert guidance has recommended it. This case has shown that it is possible to have cerebral malaria with false negative blood films and serology, especially in the context of partial prophylaxis. Although, nested PCR is highly sensitive, a recent report shows that up to two in every hundred cases are not detected by this method. ${ }^{11}$ Therefore, it may be advisable to treat those cases with a high clinical suspicion immediately, without waiting for a positive malarial screen, especially when the most sensitive tests such as malarial PCR can take several days to obtain from a reference laboratory.

\section{Learning points}

- Contrary to advice from the UK HPA, chemoprophylaxis against malaria should strongly be considered for travellers to Mumbai.

- Effective chemoprophylaxis depends on complete compliance with an efficacious antimalarial regimen.

- Cerebral malaria, a neurological manifestation of the disease, progresses rapidly and may be fatal without prompt treatment.

\section{Competing interests None.}

Patient consent Obtained.

\section{REFERENCES}

1. Health Protection Agency. Imported malaria cases and deaths, United Kingdom: 1990 - 2009. London: HPA, 8 June 2010. http://www.hpa.org. uk/Topics/InfectiousDiseases/InfectionsAZ/Malaria/EpidemiologicalData/ malaEpi10CasesandDeaths/ (last accessed on 19 June 2011).

2. Cathcart SJ, Lawrence J, Grant A, et al. Estimating unreported malaria cases in England: a capture-recapture study. Epidemiol Infect 2010;138:1052-8.

3. National Travel Health Network and Centre. India: Country Information. London: NaTHNaC, 2011. http://www.nathnac.org/ds/c_pages/country_ page_IN.htm (last accessed on 19 June 2011).

4. Zuckerman JN, editor. Principles and Practice of Travel Medicine. Chichester: John Wiley and Sons: 2001:194.

5. Ustianowski A, Schwab U, Pasvol G. Case report: severe acute symptomatic hyponatraemia in falciparum malaria. Trans $R$ Soc Trop Med Hyg 2002;96:647-8.

6. Directorate of National Vector Borne Disease Control Programme. Malaria monthly epidemiological situation. Delhi: nvbdcp, 2010. http://www.nvbdcp. gov.in/Doc/Mal-MES-Nov10.pdf (last accessed on 19 June 2011).

7. National Travel Health Network and Centre. Clinical Updates. Malaria in Maharashtra, India. 9 August 2010. London: NaTHNaC, 2010. http://www. nathnac.org/pro/clinical_updates/malaria_india_090810.htm (last accessed on 19 June 2011).

8. Srinivasan S. Malaria menace in Mumbai. Natl Med J India 2010;23:317.

9. Schmid S, Chiodini P, Legros F, et al. The risk of malaria in travelers to India. J Travel Med 2009;16:194-9.

10. Lalloo DG, Shingadia D, Pasvol G, et al. HPA Advisory Committee on Malaria Prevention in UK Travellers. UK malaria treatment guidelines. J Infect 2007:54:111-21.

11. Rodulfo H, De Donato M, Mora R, et al. Comparison of the diagnosis of malaria by microscopy, immunochromatography and PCR in endemic areas of Venezuela. Braz J Med Biol Res 2007;40:535-43. 


\section{BMJ Case Reports}

This pdf has been created automatically from the final edited text and images.

Copyright 2011 BMJ Publishing Group. All rights reserved. For permission to reuse any of this content visit http://group.bmj.com/group/rights-licensing/permissions.

BMJ Case Report Fellows may re-use this article for personal use and teaching without any further permission.

Please cite this article as follows (you will need to access the article online to obtain the date of publication).

Bhome R, Bhome R. PCR negative cerebral malaria in a traveller returning from Mumbai. BMJ Case Reports 2011;10.1136/bcr.06.2011.4371, date of publication

Become a Fellow of BMJ Case Reports today and you can:

- Submit as many cases as you like

- Enjoy fast sympathetic peer review and rapid publication of accepted articles

Access all the published articles

- Re-use any of the published material for personal use and teaching without further permission

For information on Institutional Fellowships contact consortiasales@bmjgroup.com

Visit casereports.bmj.com for more articles like this and to become a Fellow 